\title{
Social Risks and Psychological Adjustment: A Comparison of African American and South African Children
}

\author{
Oscar A. Barbarin
}

\begin{abstract}
In the United States, race is highly associated with social risk factors such as poverty and family structure that may account by themselves for developmental outcomes often attributed to race alone. This cross-national study assesses the effects of social risks on adjustment of racially similar groups of 306 African American and 625 South African 6-year-olds. Poverty and gender were confirmed as risk factors but single female headship was not. Moreover, poverty and gender posed less risk for South African than for African American children. Poverty placed children at risk for immaturity, hyperactivity, and difficulty in peer relations. Boys were more likely to have behavior problems than were girls. African Americans exhibited higher rates of emotional symptoms but lower rates of bullying, destructiveness, and social rejection than did South Africans. African Americans, particularly the males, scored higher on the opposition and hyperactivity scales than did South Africans. Distinctive social contexts and cultural resources may account for differences in adjustment.
\end{abstract}

\section{INTRODUCTION}

Considerable evidence links social risk factors such as poverty, gender, and family structure to a range of adverse psychological outcomes in children (BrooksGunn \& Duncan, 1997; Costello, 1989). For example, emotional distress, behavioral disorders, and cognitive deficits have all been associated with poverty (Capaldi \& Patterson, 1994; Werner \& Smith, 1989). The magnitude of the impact of poverty, however, appears to differ considerably by psychological domain. The largest effects are observed for cognitive development and academic achievement (McLoyd, 1998). In the same vein, Brooks-Gunn, \& Duncan (1997) report data in which effect sizes of poverty are greatest for cognitive functioning, followed by behavioral functioning, and then emotional functioning. Moreover, even though poor children are more likely than nonpoor children to present with symptoms of emotional distress and behavioral problems, poverty is inconsistently associated with higher-than-expected rates of diagnosable mental disorders as defined by the DSM IV criteria (Gore, Aseltine, \& Coldon, 1993; Hammen \& Rudolph, 1996; Whitaker et al., 1990). Recent studies also show that the effects of poverty are more pervasive and detrimental when poverty is chronic or when it occurs early in the life of the child than when it is acute, temporary, or first appears after the child has reached adolescence (McLoyd, 1998).

Gender is another widely recognized risk factor for psychological problems. Compared to girls, boys are more likely to exhibit deficits in regulation of behavior and attention (Offord, Alder, \& Boyle, 1986). They are more often conduct-disordered and undercontrolled and are more aggressive than girls. Alter- natively, girls are more likely than boys to encounter problems of emotion regulation such as irritability, depression, anxiety, and mood swings. The social risks identified in broadly representative samples of American children appear to operate in similar ways within specific populations such as African Americans. For example, Barbarin \& Soler (1993) observed, in a nationally representative sample of African American children, that young boys under 12 years of age were more likely than young girls to act impulsively, exhibit anger, break things, be withdrawn, feel worthless, have problems concentrating, be disobedient, and have problems getting along with adults. At the same time, children from single adult households tend to have more symptoms of anxiety-depression, oppositional behavior, immaturity, and difficulties with peers than children living in two-adult and multi-generational households (Barbarin \& Soler, 1993).

Race, too, has come to be viewed as a social risk factor for problems of achievement and psychological adjustment. A growing body of comparative research reveals what has been identified as the "race gap" in educational achievement (Frederick D. Patterson Research Institute, 1997). In addition, African Americans fare more poorly than do other racial groups on a host of psychological indicators. In spite of methodological limitations and conceptual problems associated with the use of race as an independent variable in the social sciences, the empirical basis of our understanding of the psychological and developmental status of African American children rests largely on a foundation of Black-White comparative research. For

(C) 1999 by the Society for Research in Child Development, Inc. All rights reserved. 0009-3920/99/7006-0007 
example, alarm about emotional and behavioral functioning arises from the comparatively higher rates of anxiety, depressive symptoms, and conduct problems found for African American children than for White children (Garrison, Jackson, Marsteller, McKeown, \& Addy, 1990; Neal, Lilly, \& Zakis, 1993; Ollendick, 1983). Comparative data on academic status of African American children paints a similar portrait of suboptimal functioning (Lyons, 1996; Stevenson, Chen, \& Uttal, 1990). Although African American and White children do not differ in reading competence in the first grade, by third grade they have significantly lower reading scores than do White children (Wood, Felton, Flowers, \& Naylor, 1991). The gap widens so quickly that by fourth grade only $31 \%$ of African American children score at or above the proficient level in reading, as compared to $71 \%$ of White students (Frederick D. Patterson Research Institute, 1997).

A variety of explanations have arisen in the public discourse about race to account for the comparatively poor outcomes of African American children. Some explanations such as genetic inferiority, inadequate moral guidance, and self-marginalizing underclass values (e.g., Herrnstein \& Murray, 1994) have been widely discredited. The validity of these accounts specifically and the interpretability of conclusions from Black-White comparative designs more generally have been questioned on both conceptual and methodological grounds (Foster \& Martinez, 1995; Kincheloe, Steinberg, \& Gresson, 1996; Suzuki \& Valencia, 1997). Conceptually, comparative studies rarely specify whether race refers to biological, cultural, or social categories. Claims for a biological explanation seem indefensible on several grounds. Methodologically, assignment to a racial group is frequently unreliable. Few studies employ an explicit verifiable procedure and rely instead on interviewer assignment based most often on observations of skin color and hair texture or on self-designations by research participants. Although self-designation is acceptable for studies which treat race as a social construct, this method provides an inadequate basis from which to draw conclusions that involve biological and genetic interpretations of race.

Because within-group genetic variability is as great as, if not greater than, between-group variation, genetic explanations do not offer a credible account of racial differences in development, particularly in light of more compelling alternatives (Kincheloe et al., 1996). Plausible explanations of the findings from racially comparative studies include poverty, stress, and stigma resulting from encounters with racist attitudes and behaviors, and the many adverse sequelae in family and community life associated with eco- nomic disadvantage (Halpern-Felsher et al., 1997). Brooks-Gunn and Duncan (1997) point out that poverty defined only in terms of low family income does not entirely explain the differences observed in child functioning. Instead, they argue, the relationship between poverty and children's outcomes may be mediated by additional factors in the community and in the family such as female headship and mother's age and educational attainment. Thus, differences between Black and White children in academic achievement and mental health may arise, for example, from family processes, from social denigration and marginalization of Blacks, or from high concentrations of poverty in Black communities that result in unequal access to resources and opportunities (Nielsen, 1997). To complicate matters even more, among African Americans, race is treated not simply as a biological/ genetic category but also as a sociocultural category that implies a distinctive set of ethnic group values or world views (e.g., see Jagers \& Mock, 1993). Effects of these putative cultural dispositions overlap with and are difficult to distinguish from the effects on children's socialization attributed to differences in economic status and social class. Thus, for African Americans, socially denigrated racial categorizations, racial identities infused with cultural meanings, and economic and political inequalities are inextricably bound. Consequently, interpretations of Black-White comparative research often do not distribute effects accurately among plausible sources that include: 1) race as a biological/genetic category, 2) race as a sociocultural category, 3) inequality of resources due to social denigration and racism, and 4) social risks related to economic status or family structure. Research intended to illuminate the effects of one of these factors without controlling for the effects of the others will be mired in ambiguity. Consequently, the use of White children as a solo comparison group in studies of African American children is a conceptually ambiguous and flawed strategy. This is an especially relevant issue in the case of phenomena that are likely to be influenced by income and social inequality, or in which questions of cultural processes are the focus of scholarly inquiry. Developmental researchers are unlikely to resist the appeal of comparative designs. Nevertheless, it seems wise to select and devise comparisons which strengthen explanatory power by minimizing or avoiding these problematic confounds.

Designs comparing one ethnic minority group with another is one approach to this problem that has been used with increasing frequency, because it offers controls for economic disadvantage and a history of social denigration. An equally attractive option involves a cross-national comparative design which 
draws economically diverse samples from identical racial groups residing in two or more nations. Accordingly, selection of South African Blacks as a comparison group to explore the effects of social risk factors on psychological and academic development of African American children is fortuitous, first because this design controls for race as a biological category, and second because such a comparison controls for the experience of discrimination and social stigma. Even a cursory examination of the social and historical conditions endured by urban South Africans reveals striking parallels to the situation of African Americans. For example, in South Africa $40 \%$ of Black families live below the poverty level in contrast to $1 \%$ of Whites. In the United States, approximately $46 \%$ of Black children live in poverty compared to only $14 \%$ of White children. The relative economic disadvantage endured by South Africans and African Americans can be traced to a history of racial oppression that is fueled by educational inequality and sustained by extraordinarily high rates of unemployment. As a consequence, both groups suffer inordinately from hunger, nutritional deficiencies, inadequate housing, cycles of rural-urban migration, degradation of physical environment, exposure to pollution and toxins, and unequal access to health care (Barbarin \& Khomo, 1997). The social challenges and community problems confronting South Africans resonate within African American communities: rising numbers of children born to unmarried women living in poverty, concerns about crime and violence, child abuse and neglect, and spiraling rates of substance abuse which tear apart the fabric of family life (Richter, 1994).

Depending on the sampling design, cross-national comparisons which hold constant the variable of racial categorization can facilitate testing of the impact of cultural resources or social risk factors on children's adjustment. For example, the effects on development of risks associated with material inadequacy or parental marital status can be distinguished from effects of membership in a stigmatized group by comparing children from groups that have similar histories of racial discrimination. By minimizing the confound of racial group identity and economic status, this approach offers a more stringent test of the effects of poverty or of being raised in a single adult household headed by an unmarried mother. In this way, crossnational comparison of African American and South African children is an attractive option.

Although the similarities are substantial, significant differences are also noted between African Americans and South African Blacks with respect to family life, history, culture, geography, language, minority status, and experience of colonization. A subtle but impor- tant difference is that, unlike African Americans, South African Blacks constitute an overwhelming majority in their own country where they make up approximately $79 \%$ of the South African population of 37.5 million. Majority status may afford Black South Africans a psychological advantage not enjoyed by African Americans. In addition, Black South Africans organize themselves into ethnic, clan, and family groupings which forge a common identity through shared languages, traditions, and ideologies. These ethnic group identifications bring with them culturally defined views, for example, of childhood and gender roles that are reflected in socialization goals, discipline, and expectations of unquestioning compliance with parental, familial, and male authority (Richters, 1993). The ability to control for racial categorization and discrimination in comparisons between South Africans and African Americans opens the possibility of testing the independent effects of social risks and resources on children's psychological development.

\section{RESEARCH QUESTIONS}

The extent to which factors identified as social risks in the United States have similar effects in other national contexts is unclear. For example, growing up as a black, poor, and female child of an unmarried mother may involve a different experience and have different significance in South Africa than in the United States. These differences, in turn, may augment or attenuate the hazards associated with gender, poverty, and family structure. With respect to racial group identity, being among the majority may convey to Black South Africans a psychological advantage in the form of selfefficacy and hope not enjoyed by African Americans. Perhaps majority status confers protection against the effects of racially based social and economic inequality on emotional and behavioral problems. In light of the majority status and cultural differences, will the consequences of economic status, family structure, and gender for behavioral, emotional, and academic functioning be the same for South African Blacks as it is for African American children growing up in the United States? The cross-national comparisons undertaken here offer the advantage of controlling for socioeconomic status and racial subordination, thus making possible a clearer test of the relation of psychological adjustment to other social risks and cultural resources.

\section{METHOD}

Participants include a sample of 625 Black children representative of the Birth-to-Ten longitudinal study 
cohort from the Black townships within the metropolitan area of Johannesburg, South Africa, and 306 African American children selected as part of a nationally representative sample of American children. All children were between 5 and 6 years old at the time of interview.

Sample 1: African American sample and data collection procedure. Data from the African American sample reported in this paper were collected as part of the 1988 National Health Interview Survey, the Child Health Supplement (NHIS-CHS), under the auspices of the United States Department of Health and Human Services, the National Center for Health Statistics (National Center for Health Statistics, 1988). The National Health Interview Survey (NHIS) provided a summary of the child's physical and social development and targeted, specifically, symptoms of physical illness, emotional difficulties, and behavioral disorders. The purpose of the NHIS was to gather information about physical developmental and psychological conditions of children. Trained project staff visited children's homes to conduct face-to-face interviews with parents or parental surrogates. They posed structured questions on health status, school adjustment, problems of learning, and psychological functioning. The information was used to identify service needs of children and their families. Additional information was gathered on household composition; demographic status of the biological mother, father, and primary care taker; and data related to pregnancy, birth, and child care. The universe of the sample was a civilian noninstitutionalized population of the 50 states and the District of Columbia. The sampling methodology involved a multistage probability sample from 1,924 geographically defined primary sampling units. When more than one child resided in a selected household, a single target child was randomly selected from each household. The resulting sample is therefore a representative sample of the population of the United States, with a large national probability sample of African American children aged 0 to 17 years.

Sample 2: South African sample and data collection procedure. The South African data were collected as part of the Birth-to-Ten study (BTT), a longitudinal study of the effects of urbanization on physical growth and psychological development (Richter, Yach, Cameron, Griesel, \& deWet, 1995). The group of children whose data are reported here represent a subgroup of children primarily from Black townships. The entire sample was a prospective birth cohort of all children born in the seven-week period from March 23 to May 7, 1990 in the Johannesburg-Soweto metropolitan area. The sampling procedure and its outcome are described in greater detail elsewhere (Barbarin \& Khomo, 1997).
Mothers or primary caregivers of the children were recruited into the study at several different points until the cohort reached the age of 1 year. Extensive data on physical growth, psychological development, and family life were collected in data waves in 1992, 1994, and 1995. The data reported here were collected between January and April 1996 by trained interviewers fluent in a variety of languages spoken by Black South Africans in the Guateng Province: Zulu, South Sothto, Tswana, Xhosa, English, and Afrikaans. Interviews were conducted by five trained multilingual community residents who had experience in collecting similar data from prior BTT panels.

\section{MEASURES}

Poverty index. To assess the effects of material hardship on children's behavioral and emotional adjustment, indices of poverty were assessed for each family. In both the United States and South Africa, standards have been developed by the national government which are sensitive to a local context for assessing material hardship and poverty (U.S. Bureau of the Census, 1993; Bureau of Market Research, 1995). For the sample in the United States, the United States government poverty standard was utilized; children falling at or below the poverty line were designated as poor, and those falling above it were designated as not poor. Generally these guidelines are based on the amount of funds needed to provide a minimally adequate food supply plus a small allowance for housing and other costs. The most recent poverty line for a family of four - two adults and two children-is approximately $\$ 14,000$. In the African American sample, $44 \%$ of the children live below the poverty line. For the most part, the social and economic conditions in South Africa-characterized by high unemployment (estimated by the World Bank at $40 \%$ ), low wage rates, and nonmonetary methods of consumption-were emphasized in poverty designations. Therefore, consumption rather than income was used to estimate economic status and assign South African families to poverty groups (Barbarin \& Khomo, 1997). Consumption was measured in terms of expenditures for housing, utilities, appliances, and transportation. In our South Africa sample, $57 \%$ of the children lived in households which were at or below the median consumption level for our urban sample. For the purposes of this study these children were designated as the poor.

Family structure index. Previous research suggests that several key family structures may account for significant differences related to levels of behavioral and emotional adjustment; one of the key factors is whether the parent is the single adult in the house- 
hold or has a partner to aid in parenting. This variable is used to test the effects of family structure. Single parents are those who live with dependent children with no other adults in the household. For both the South African and African American samples, the majority of single adults were women; only $5 \%$ were men, mostly fathers and a few grandfathers. The female solo parents consisted of mothers, grandmothers, and aunts. While most of the multiple-adult households consisted of biological mothers and fathers, household constellations also included grandparents or aunts and their spouses, or mothers and their mothers or sisters.

Behavior problem index. The Behavior Problem Index (BPI; Zill, 1985) was developed for the NHIS and used as an index of significant behavioral problems with clinical cutoff scores (total raw score of 14, or 90th percentile) that effectively differentiated between children referred and those not referred for mental health services (Bussing, Halfon, Benjamin, \& Wells, 1995). Items were selected by a group of developmental consultants from extant screening tools assessing behavior and emotional adjustment of children aged 4 years and older (Achenbach, Howell, Quay, \& Conners, 1991). The evidence supporting the construct validity and reliability of the BPI scales is substantial (Peterson \& Zill, 1986; Zill, 1985). Subscales for the BPI were developed using a principle components analysis of items. The factor analysis yielded five scales made up of the sum of constituent items scored 0 or 1 . Estimates of internal consistency average about 85 for young children (Bussing et al., 1995). The scales are as follows

Anxiety/depression includes symptoms normally categorized under the rubric of internalizing disorders. They refer generally to emotional agitation and disturbances of mood or affect. This scale contains five items: mood changes, feeling unloved, fearfulness, worthlessness, and sadness.

Immaturity is a four-item scale that refers to excessive dependence on others, particularly adults. It is suggestive of a lack of self-assurance. High scores in this item suggest a lack of autonomy and overly dependent behavior.

Oppositional behavior assesses treated disposition, best characterized as difficult to control and influence. Scores indicate the extent to which the child is noncompliant. This scale contains six items: stubbornness, strong temper, disobedience at home, disobedience at school, arguing, and being high strung.

Hyperactivity assesses the constellation of behavioral symptoms - such as difficulty in concentration and maintaining cognitive focus-so often associated with attention deficit disorder. It also includes heightened activity and inability to inhibit or control movement that is synonymous with hyperactivity. The scale contains five items pertaining to inability to concentrate, being easily confused, impulsivity, and restlessness.

Social problems measures social withdrawal and problems in social functioning. The five items making up this scale assess shyness, social withdrawal, peer acceptance, and the extent to which the child is able to get along with other children.

The substantial cultural and linguistic differences between the United States and South Africa undoubtedly complicate issues of measurement and interpretation of findings. Consultation with a group of parents was undertaken to assess the clarity, sensitivity, and relevance of measures to parenting as construed by South Africans. Adaptations were made in language and content to address concerns identified in pilot studies prior to using these measures. For example, "to make a face" was substituted for "to pout" because the latter expression is not in common use among South African Blacks. (Questions used in the study are available from the author.) Typically, the BPI was completed by the mother or primary guardian. For each of the 25 BPI items included in this study, the respondent indicated whether it was often true, sometimes true, or not true of the target child. This study adopted a stringent scoring approach, summing up only those items for which the respondent indicated that it was often true, because by inference these represented the most serious manifestations of the symptom.

\section{RESULTS}

Demographic profiles. A comparison of the South African and African American samples suggests that they are relatively similar along a number of important dimensions. Statistical tests reveal no significant differences between the two groups with respect to gender composition, maternal education, and maternal employment. In both samples there is a relatively even distribution of males and females. With respect to parents, only one of five mothers in each sample had education beyond the high school level, and two of every three mothers described themselves as employed or seeking employment. However, South African mothers are significantly younger $(M=25.1$, $S D=6.4)$ than the mothers of the African American sample $(M=27.1, S D=9.5), F(1,928)=13.3, p=.001$.

Hollingshead Social Class Factor scores were computed for households in both nations (Hollingshead, 1957). No differences were observed in the proportion of South African and African American households at the lowest end of the SES spectrum. Moreover, with the exception of Class I, the two samples have roughly 
the same proportion of households in each of the Hollingshead social class groupings. Over one third of both groups were assigned to the lowest Hollingshead social class. However, very few in the South African household sample are in the top social class (I), and about 1 in 10 African American families could be categorized as Class I. Likewise, African American children were less likely than South African children to live in households that fell below the poverty lines of their respective countries. This may be due to the extraordinarily high rate of Black unemployment, large household size, and absence of a social welfare system for Blacks in South Africa.

With respect to family structure and household composition, there is again rough parity between the South African and African American samples. The two groups are equivalent with respect to the proportion of mothers who were married, and close in the proportion of households headed by single mothers. A much larger proportion of the South African mothers have never been married but live with partners. Although mothers in the South African sample are younger, the size of South African households is larger $(M=7.2, S D=3.4)$ than the African American families $(M=4.1, S D=1.7), F(1,928)=229.3, p=$ .001. Significant differences between African American and South African samples occur with respect to nonmaternal figures residing in the household with mother and children. Grandmothers resided with mother and child in one of three South African families but in only one of five African American families. The significantly larger household size for South Africans is due not only to the larger number of dependent children but also to the greater likelihood of multiple generations living in the same home. Newly formed families find it increasingly difficult to obtain housing. By policy, the former apartheid government in South Africa constrained the supply of new housing in urban areas. Thus the high rate of multigenerational households resulted from a combination of poverty, acute housing shortages for urban Blacks, and historical cultural patterns of living arrangements such as family compounds in which extended family members live in close proximity. In spite of the comparatively lower marital rate for South African mothers, South African children were more likely than their African American counterparts to reside with a father figure. This may in fact represent both an acceptance of informal marriages and cohabitation among those who intend to marry but who cannot afford Labola ${ }^{1}$

\footnotetext{
${ }^{1}$ Labola are obligatory payments somewhat like dowries paid to the family of the bride. Traditionally these were in the form of cattle but in urban areas they took the form of cash payments or material goods.
}

Table 1 Demographic Profile of the African American and South African Samples

\begin{tabular}{lccc}
\hline & $\begin{array}{c}\text { African } \\
\text { Americans } \\
(n=306)\end{array}$ & $\begin{array}{c}\text { South } \\
\text { Africans } \\
(n=625)\end{array}$ & \multicolumn{1}{c}{$\chi^{2}$} \\
\hline $\begin{array}{l}\text { \% Male } \\
\text { Mother's education, less }\end{array}$ & $52.3 \%$ & $49.6 \%$ & $n s$ \\
$\quad$ than high school & $83.0 \% * * *$ & $83.0 \%$ & \\
Mother in labor force & $63.7 \%$ & $65.9 \%$ & \\
Marital status & & & \\
$\quad$ Never married & $40.4 \%$ & $59.7 \%$ & \\
$\quad$ Widowed/divorced & $23.9 \%$ & $5.2 \%$ & $\chi^{2}(2)=73.6^{* *}$ \\
$\quad$ Married & $35.7 \%$ & $35.1 \%$ & \\
Father figure in home & $49.7 \%$ & $60.3 \%$ & $\chi^{2}(2)=9.49^{*}$ \\
Grandmother in home & $19.0 \%$ & $32.8 \%$ & $\chi^{2}(2)=19.4^{* *}$ \\
Single adult, female- & & & \\
$\quad$ headed household & $39.2 \%$ & $33.4 \%$ & \\
Hollingshead two-factor & & & \\
$\quad$ social class rating & & & \\
$\quad$ Class I (highest) & $10.5 \%$ & $.3 \%$ & \\
$\quad$ Class II & $8.2 \%$ & $13.0 \%$ & \\
$\quad$ Class III & $18.3 \%$ & $17.8 \%$ & \\
$\quad$ Class IV & $26.1 \%$ & $31.6 \%$ & \\
$\quad$ Class V (lowest) & $36.9 \%$ & $37.3 \%$ & \\
Percent living in poverty & $44.1 \%$ & $57.1 \%$ & $\chi^{2}(2)=13.8^{* *}$ \\
\hline * $<$.05; ** $p<.01 ; * * *<.001$. & &
\end{tabular}

offerings to the woman's family, and the greater likelihood for multiple generations to reside in the same household. (See Table 1 for the demographic data for each sample.)

Heirarchical log linear analysis of symptom frequencies. Table 2 presents the results of the hierarchical log linear analysis which examined the relation of national origin and gender to the prevalence of behavioral and emotional symptoms among children in the study. In addition, the analysis tested the significance of the nation $\times$ gender interaction on the occurrence of symptoms. Children who do not have serious difficulties will occasionally exhibit many of these symptoms. Consequently, a conservative approach to scoring the items considers the symptom as contributing to a pattern of difficulty only when the parent indicates that it occurs often. Accordingly, the log linear analysis is applied to the responses, recoded so that "never occurs" and "sometimes occurs" become 0 , and "often occurs" becomes 1.

Across both samples, high proportions of children were characterized as restless, squirming, and frequently demanding attention. The results of the partial $\chi^{2}$ for the effects of national origin reveal significant differences on 17 of the 25 symptoms. African 
Table 2 Hierarchical Log Linear Analysis: Cell Percentages and Partial $\chi^{2}$ Testing Significance of the Associations between National Origin, Gender, and Interaction with BPI Symptoms

\begin{tabular}{|c|c|c|c|c|c|c|c|c|}
\hline & \multicolumn{2}{|c|}{ African Americans } & \multicolumn{2}{|c|}{ South Africans } & \multirow[b]{2}{*}{ Total } & \multicolumn{3}{|c|}{ Partial $\chi^{2}$} \\
\hline & $\begin{array}{c}\text { Boys } \\
(n=160)\end{array}$ & $\begin{array}{c}\text { Girls } \\
(n=146)\end{array}$ & $\begin{array}{c}\text { Boys } \\
(n=310)\end{array}$ & $\begin{array}{c}\text { Girls } \\
(n=315)\end{array}$ & & Nation & Gender & $\begin{array}{c}\text { Nation } \times \\
\text { Gender }\end{array}$ \\
\hline Anxious & 35.6 & 35.6 & 8.7 & 7.9 & 17.2 & $100.61^{* * *}$ & & \\
\hline Argues & 42.5 & 38.4 & 43.2 & 43.8 & 42.5 & & & \\
\hline Disobedient at school & 27.5 & 11.6 & 8.4 & 5.1 & 11.1 & $33.47^{* * *}$ & $13.86^{* * *}$ & \\
\hline Breaks rules & 18.1 & 17.1 & 29.4 & 21.6 & 22.9 & $7.61^{* * *}$ & $4.09^{*}$ & \\
\hline Impulsive & 37.5 & 30.8 & 40.3 & 33.7 & 35.5 & & $4.50^{*}$ & \\
\hline Withdrawn & 8.1 & 5.5 & 7.1 & 5.4 & 6.4 & & & \\
\hline Destroys others' possessions & 14.4 & 4.8 & 41.6 & 26.7 & 26.1 & $74.10^{* * *}$ & $22.69^{* * *}$ & \\
\hline Mood changes & 46.3 & 41.1 & 38.1 & 36.5 & 39.4 & & & \\
\hline Worthless & 2.5 & 6.2 & 4.5 & 2.9 & 3.9 & & & $3.72 *$ \\
\hline Complains about love & 18.1 & 19.9 & 9.0 & 10.8 & 12.9 & $11.05^{* * *}$ & & \\
\hline Sad & 10.0 & 8.9 & 4.5 & 1.6 & 5.2 & $15.84^{* * *}$ & & \\
\hline Nervous & 3.0 & 2.9 & 1.8 & 1.3 & 2.0 & $66.66^{* * *}$ & & \\
\hline Dependent & 36.9 & 33.6 & 25.2 & 29.4 & 29.9 & $6.40^{* *}$ & & \\
\hline Disobedient at home & 36.3 & 29.5 & 10.6 & 8.9 & 17.4 & $72.30^{* * *}$ & & \\
\hline Stubborn & 43.1 & 38.4 & 47.7 & 34.6 & 41.1 & & $10.44^{* * *}$ & \\
\hline Temper tantrums & 30.0 & 23.3 & 19.7 & 18.1 & 21.5 & $7.28^{* *}$ & & \\
\hline Unable to concentrate & 43.8 & 28.8 & 18.7 & 18.4 & 24.5 & $43.38^{* * *}$ & & $4.02^{*}$ \\
\hline Confused & 16.9 & 12.3 & 2.3 & 3.2 & 6.7 & $43.86^{* * *}$ & & \\
\hline Bullies, cruel, mean & 17.5 & 12.3 & 43.9 & 32.4 & 30.5 & $57.35^{* * *}$ & $10.34^{* * *}$ & $4.56^{*}$ \\
\hline Unable to get mind off certain things & 19.4 & 12.3 & 16.8 & 16.2 & 16.3 & & & \\
\hline Squirms, restless & 50.0 & 45.9 & 50.3 & 53.7 & 50.7 & & & \\
\hline Clings to adults & 23.8 & 15.8 & 13.9 & 12.7 & 15.5 & $6.40^{* *}$ & & \\
\hline Cries without reason & 28.8 & 21.2 & 10.6 & 12.4 & 16.0 & $26.84^{* * *}$ & & \\
\hline Demands attention & 48.1 & 41.1 & 56.1 & 61.9 & 54.4 & $16.73^{* * *}$ & & $3.50^{*}$ \\
\hline Not liked by other children & 6.9 & 3.4 & 8.4 & 9.5 & 7.7 & $14.29^{*}$ & & \\
\hline
\end{tabular}

${ }^{*} p<.05 ; * * p<.01 ; * * * 0.001$.

American children had higher prevalence rates than did the South Africans on 12 of the 17 items for which significant national origin effects were found, (viz., anxiety, nervousness, sadness, disobedience at home and school, temper tantrums, concentration problems, being confused, complaining about love, dependence, clinging to an adult, and crying without reason). South Africans, however, had higher prevalence rates for symptoms related to social and behavioral adjustment, such as breaking the rules, destroying others' possessions, bullying, not being liked by others, and demanding attention.

With respect to gender, boys more often than girls were rated as evidencing symptoms of disruptive behavior such as disobeying, breaking rules, acting impulsively, destroying others' possessions, and bullying or acting with cruelty. A significant interaction between national origin and gender was observed for problems of concentration. In this case, African American boys were much higher than any other group. Moreover, the differences in concentration between boys and girls in the South African sample were negligible, but African American boys were significantly more likely than African American girls to evidence concentration problems. A similar pattern obtains with respect to bullying behavior: African American boys scored significantly higher than did girls; South African boys and girls were not different, and as a group their scores were higher than those of African Americans. A different pattern occurs with respect to feelings of worthlessness. African American girls and South African boys are more frequently rated as often feeling worthless. The exact opposite patterns occur for demanding attention, where the South African girls and African American boys are higher than their gender counterparts.

Multiple analysis of variance (MANOVA). The individual symptom items from the BPI combine linearly to comprise five distinct scales: anxiety/depression, immaturity, oppositional behavior, hyperactivity, and social problems. These five scales were entered as dependent variables into a MANOVA. The independent variables for this analysis included national origin, poverty status, and gender. When we tested the main effects and interactions, several factors emerged as significant on the test for overall multivariate effect. First, 
the overall multivariate $F$ value for national origin was significant, $F(5,918)=14.02, p \leq .001$. Also significant were the main effects for poverty, multivariate $F(5,918)=3.98, p \leq .001$, and gender, multivariate $F(5,918)=2.47, p \leq .03$. Two interactions approached significance: nation $\times$ poverty status, multivariate $F(5,918)=2.15, p \leq .05$, and nation $\times$ gender, multivariate $F(5,918)=2.16, p \leq .05$. The two-way interaction between poverty status and gender, and the threeway interaction between nation, poverty status, and gender, were not significant.

Table 3 presents the means and standard deviations for the behavior problem inventory subscales by national origin, poverty status, and gender. In examining the significance of the univariate $F$ for the main effects and interactions on which multivariate $F$ s were significant, we noted several distinct patterns. The univariate $F$ values for the main effect of national origin were significant for anxiety/depression, $F(1,928)=$ 57.09, $p \leq .001$, immaturity, $F(1,928)=3.83, p \leq .05$, oppositional behavior, $F(1,928)=29.56, p \leq .001$, and social problems, $F(1,928)=4.73, p \leq .03$. In each case, the African American children scored significantly higher on these problems than did the South African children. When we examine the univariate $F$ values for poverty status, we observe a significant $F$ value for immaturity, $F(1,929)=5.03, p \leq .03$, hyperactivity, $F(1,929)=13.4, p \leq .001$, and social problems, $F(1,929)=9.86, p \leq .002$. In each case, poor children score significantly higher on problem scales than do children from more advantaged backgrounds.

Significant univariate $F$ s are found for gender on oppositional behavior, $F(1,928)=6.65, p \leq .01$, and hyperactivity, $F(1,928)=9.39, p \leq .002$. Inspection of the means shows that boys score significantly higher than girls on opposition and hyperactivity.

In interactions between national origin and poverty status, we find significant univariate $F$ s for anxiety/depression, $F(1,926)=4.00, p \leq .05$, and for hyperactivity, $F(1,926)=5.89, p \leq .015$. Inspection of the means for the four groups suggests that the difference on anxiety between the nonpoor and poor for African Americans is greater than the difference between nonpoor and poor South Africans. A similar pattern obtains for hyperactivity.

Significant univariate $F$ s for the nation $\times$ gender interaction were found for immaturity, $F(1,926)=$ $5.12, p \leq .02$ and for hyperactivity, $F(1,926)=3.87$, $p \leq .05$. Again, inspection of the means related suggest that gender differences are much greater for African Americans than they are for South Africans.

To test the effects of family structure-specifically single parenthood - a four-way MANOVA was computed in which national origin, poverty status, gender, and single parenthood were the independent factors. The main effect for family structure was not significant nor was there a significant interaction between parenthood and any of the other variables, whether two-way, three-way, or four-way. Thus, single parenthood does not explain the variance on behavior problems beyond what can be accounted for by poverty status.

\section{DISCUSSION}

This research analyzes differences between South African Blacks and African American children in psychological adjustment, and evaluates the cross-cultural

Table 3 Means and Standard Deviations for BPI Subscale by National Origin, Poverty Status, and Gender

\begin{tabular}{|c|c|c|c|c|c|c|c|c|c|c|c|c|c|c|c|c|}
\hline & \multirow[b]{3}{*}{$n$} & \multicolumn{7}{|c|}{ African Americans } & \multicolumn{7}{|c|}{ South Africans } & \multirow{3}{*}{$\begin{array}{c}\text { Grand } \\
\text { Total } \\
(930)\end{array}$} \\
\hline & & \multicolumn{3}{|c|}{ Poor } & \multicolumn{3}{|c|}{ Nonpoor } & \multirow[b]{2}{*}{$\begin{array}{l}\text { Total } \\
(306)\end{array}$} & \multicolumn{3}{|c|}{ Poor } & \multicolumn{3}{|c|}{ Nonpoor } & \multirow[b]{2}{*}{$\begin{array}{l}\text { Total } \\
(624)\end{array}$} & \\
\hline & & $\begin{array}{c}\text { Boys } \\
(67)\end{array}$ & $\begin{array}{c}\text { Girls } \\
(68)\end{array}$ & $\begin{array}{l}\text { Both } \\
(135)\end{array}$ & $\begin{array}{c}\text { Boys } \\
(93)\end{array}$ & $\begin{array}{c}\text { Girls } \\
(78) \\
\end{array}$ & $\begin{array}{l}\text { Both } \\
(171) \\
\end{array}$ & & $\begin{array}{l}\text { Boys } \\
(129)\end{array}$ & $\begin{array}{l}\text { Girls } \\
(139)\end{array}$ & $\begin{array}{l}\text { Both } \\
(268)\end{array}$ & $\begin{array}{l}\text { Boys } \\
(180)\end{array}$ & $\begin{array}{l}\text { Girls } \\
(176)\end{array}$ & $\begin{array}{l}\text { Both } \\
(356)\end{array}$ & & \\
\hline $\begin{array}{l}\text { Anxiety/ } \\
\text { depression }\end{array}$ & $\begin{array}{l}M \\
S D\end{array}$ & $\begin{array}{l}1.34 \\
(1.3)\end{array}$ & $\begin{array}{c}1.13 \\
(1.3)\end{array}$ & $\begin{array}{c}1.24 \\
(1.3)\end{array}$ & $\begin{array}{r}.97 \\
(1.1)\end{array}$ & $\begin{array}{r}1.10 \\
(1.3)\end{array}$ & $\begin{array}{c}1.03 \\
(1.2)\end{array}$ & $\begin{array}{c}1.12 \\
(1.2)\end{array}$ & $\begin{array}{l}.69 \\
(.8)\end{array}$ & $\begin{array}{l}.63 \\
(.8)\end{array}$ & $\begin{array}{l}.66 \\
(.8)\end{array}$ & $\begin{array}{l}.62 \\
(.9)\end{array}$ & $\begin{array}{l}.57 \\
(.8)\end{array}$ & $\begin{array}{l}.60 \\
(.8)\end{array}$ & $\begin{array}{l}.62 \\
(.8)\end{array}$ & .79 \\
\hline Immaturity & $\begin{array}{l}M \\
S D\end{array}$ & $\begin{array}{l}1.48 \\
(1.5)\end{array}$ & $\begin{array}{c}1.31 \\
(1.4)\end{array}$ & $\begin{array}{r}1.39 \\
(1.4)\end{array}$ & $\begin{array}{c}1.30 \\
(1.4)\end{array}$ & $\begin{array}{r}.95 \\
(1.1)\end{array}$ & $\begin{array}{c}1.14 \\
(1.3)\end{array}$ & $\begin{array}{r}1.25 \\
(1.4)\end{array}$ & $\begin{array}{l}1.06 \\
(1.1)\end{array}$ & $\begin{array}{r}1.07 \\
(1.0)\end{array}$ & $\begin{array}{r}1.07 \\
(1.0)\end{array}$ & $\begin{array}{l}1.06 \\
(.9)\end{array}$ & $\begin{array}{c}1.23 \\
(1.0)\end{array}$ & $\begin{array}{l}1.15 \\
(1.0)\end{array}$ & $\begin{array}{c}1.11 \\
(1.0)\end{array}$ & $\begin{array}{r}1.16 \\
(1.1)\end{array}$ \\
\hline Opposition & $\begin{array}{l}M \\
S D\end{array}$ & $\begin{array}{r}2.03 \\
(1.7)\end{array}$ & $\begin{array}{r}1.47 \\
(1.6)\end{array}$ & $\begin{array}{l}1.75 \\
(1.7)\end{array}$ & $\begin{array}{l}1.54 \\
(1.6)\end{array}$ & $\begin{array}{l}1.55 \\
(1.5)\end{array}$ & $\begin{array}{c}1.54 \\
(1.5)\end{array}$ & $\begin{array}{l}1.63 \\
(1.6)\end{array}$ & $\begin{array}{r}1.21 \\
(1.1)\end{array}$ & $\begin{array}{l}1.01 \\
(.9)\end{array}$ & $\begin{array}{c}1.10 \\
(1.0)\end{array}$ & $\begin{array}{c}1.31 \\
(1.1)\end{array}$ & $\begin{array}{r}1.15 \\
(1.0)\end{array}$ & $\begin{array}{r}1.23 \\
(1.1)\end{array}$ & $\begin{array}{l}1.18 \\
(1.1)\end{array}$ & $\begin{array}{r}1.33 \\
(1.3)\end{array}$ \\
\hline Hyperactivity & $\begin{array}{l}M \\
S D\end{array}$ & $\begin{array}{l}1.82 \\
(1.5)\end{array}$ & $\begin{array}{c}1.31 \\
(1.5)\end{array}$ & $\begin{array}{c}1.56 \\
(1.5)\end{array}$ & $\begin{array}{c}1.23 \\
(1.3)\end{array}$ & $\begin{array}{r}.95 \\
(1.1)\end{array}$ & $\begin{array}{r}1.10 \\
(1.2)\end{array}$ & $\begin{array}{r}1.30 \\
(1.4)\end{array}$ & $\begin{array}{l}1.28 \\
(1.0)\end{array}$ & $\begin{array}{c}1.22 \\
(1.2)\end{array}$ & $\begin{array}{c}1.34 \\
(1.2)\end{array}$ & $\begin{array}{c}1.31 \\
(1.1)\end{array}$ & $\begin{array}{c}1.19 \\
(1.0)\end{array}$ & $\begin{array}{r}1.25 \\
(1.1)\end{array}$ & $\begin{array}{c}1.28 \\
(1.0)\end{array}$ & $\begin{array}{r}1.29 \\
(1.1)\end{array}$ \\
\hline Social problems & $\begin{array}{l}M \\
S D\end{array}$ & $\begin{array}{l}.34 \\
(.7)\end{array}$ & $\begin{array}{l}.24 \\
(.6)\end{array}$ & $\begin{array}{l}.29 \\
(.6)\end{array}$ & $\begin{array}{l}.19 \\
(.5)\end{array}$ & $\begin{array}{l}0 \\
(.29)\end{array}$ & $\begin{array}{l}.15 \\
(.4)\end{array}$ & $\begin{array}{l}.21 \\
(.5)\end{array}$ & $\begin{array}{l}.12 \\
(.3)\end{array}$ & $\begin{array}{l}.14 \\
(.4)\end{array}$ & $\begin{array}{l}.13 \\
(.4)\end{array}$ & $\begin{array}{c}.18 \\
(.4)\end{array}$ & $\begin{array}{l}.16 \\
(.4)\end{array}$ & $\begin{array}{l}.17 \\
(.4)\end{array}$ & $\begin{array}{l}.15 \\
(.4)\end{array}$ & $\begin{array}{r}.17 \\
(.4)\end{array}$ \\
\hline
\end{tabular}


robustness of several social risk factors. Taken together, the results of the log linear analysis and the MANOVA analyses suggest interesting differences for behavioral and emotional problems among young African American and South African children. Overall, African American children evidenced greater prevalence for most, though not all, symptoms and scored higher than South African children with respect to the clinical scales. For example, the symptom-level data show that African American children scored much higher on the emotional symptoms such as anxiety, nervousness, sadness, complaining about love, and dependence, than did the South African children. In addition, African American children scored significantly higher than South Africans on the scale scores for anxiety/depression, immaturity, opposition, and hyperactivity. These data lead to the conclusion that African Americans are, in general, more troubled and more susceptible to risk of psychological dysfunction than are South Africans. African American boys, in particular, evidenced a pattern of heightened vulnerability for behavioral and emotional difficulties. For example, of all groups in the study, African American boys have the greatest difficulty with concentration problems. It is not immediately evident why African American boys should have more difficulty in this area than African American girls. Plausible explanations include gender-differentiated socialization, and biological vulnerability early in life which compound the effects of other risks such as malnutrition and early exposure to toxins and metals that severely compromise neurological development necessary for acquisition of self-regulation (Politt \& Gorman, 1994).

Although African American children evidence behavioral and emotional difficulties to a significantly greater extent than South African children, South Africans evidence greater vulnerability within a subset of symptoms related to antisocial and disruptive behavior. Specifically, South Africans were rated much higher on symptoms such as bullying, breaking rules, destroying others' property, not being liked by others, and demanding attention. These data suggest a differential pattern of dysfunction-namely, African American children tend to have greater vulnerability with respect to internalizing symptoms, suggestive of overregulation among African Americans, and South African children have greater vulnerability to socially disruptive behavior, suggestive of suboptimal regulation (Hammen \& Rudolph, 1996). The differences may be related to high levels of disruption in family and community life associated with political turmoil in South Africa and the wave of violent criminal activity that has risen in its place (Barbarin, Richter, de Wet, \& Wachtel, 1998). In addition, the excesses of physical punishment at home and at school, ethnic conflict, and a steadily increasing wave of criminal violence may create in children the unmistakable impression that violence and coercion are socially acceptable and sanctioned strategies for resolving interpersonal difficulties (McKendrick \& Senoamadi, 1996; Swarts, 1997). Moreover, during the protracted period of the liberation struggle against apartheid, defiance of authority became an accepted norm, particularly among youth. This sentiment may still be commonplace in the post-apartheid transformation period.

Poverty, family structure, and gender have broad empirical support as risk factors for behavioral and emotional difficulties (Barbarin \& Soler, 1993). The evidence from this study is consistent, for the most part, with the existing research on these issues. The gender differences expected on the basis of this earlier work were found for behavior and conduct problems. Predictably, boys were more often rated as having conduct problems than were girls. However, our data do not provide support for differences between girls and boys on emotional symptoms. Poverty was also confirmed as a risk factor. Poor children scored significantly higher on immaturity, hyperactivity, and social problems than nonpoor children. However, family structure, as indexed by single parenthood, was unrelated to children's behavioral and emotional adjustment when poverty status was controlled. This finding is important because so much of the data confirming a relation between single-adult households and poor development fail to control for the confound of economic status. If economic status is the active ingredient, then policy efforts focused exclusively on marital and family life are misguided at best.

Although poverty and gender are confirmed as risk factors for African American children, this is not the case for South African children. Why are South African children protected relative to African Americans? Possible explanations include the psychological protections afforded by majority status and the stressbuffering resources of support from extended family networks.

Even though South African children grow up under conditions that are as adverse as, if not more adverse than, those for African Americans, the social and cultural context may afford them some protections not available to African American children. A different consciousness of self, founded in the perception of self as part of a majority group, may be an important resource for South African children and their families. This notion could be tested by comparisons of African Americans and Africans to the mixed race groups in South Africa classified under the apartheid system as Coloured - a mixed race group formed from a combi- 
nation of Whites, Africans, and Malay Indians. If the supposition about the effect of majority status is accurate, African children would show better outcomes than both Coloured and African American. Many Coloureds, by language, culture, and politics, tend to identify more with Afrikaans- speaking Whites than with Black Africans. In the shifting landscape of South Africa's racial group politics, Coloured children, situated uncomfortably between Whites and Africans, occupy an uncertain position in the Blackmajority ruled democracy. Absent the psychological protections afforded Blacks by their majority status, the position of Coloureds is analogous to that occupied by Blacks in the United States. For this reason, it could be argued that comparisons of Coloureds to African Americans would reveal less striking differences in psychological adjustment.

Another explanation is that a more adequate foundation of social and material support is available to South African parents who are living in multigenerational households (which tend to be more of a standard). The forces of apartheid, by limiting the supply of housing, may inadvertently have contributed to a level of family interdependence which makes some form of adult nurturing and guidance more consistently available to children than is the case among African Americans. Moreover, ideological resources may be available to South African families from the resistance struggle to seek liberation from apartheid. Participation in the liberation movement may help form explanatory schemas that permit families to transcend the demoralizing effects of adversity by reinterpreting it as an externally imposed condition. Moreover, retention of traditional family practices in a modified form (ritualization; family, clan, or ethnic group identification) also affords protection to the developing child.

In the absence of confirming empirical data, these ideas amount to little more than plausible speculations. Additional research might examine other cultural resources and identify the ways in which they impact on child development.

It is hoped that the data on South African-African American differences presented here will stimulate more focused investigations of the social and cultural contexts of psychological adjustment and development (e.g., Robertson \& Kottler, 1993). Advancement of knowledge about these issues may result from several lines of research. At the heart of suggestions for future research are efforts to understand how differing conceptions of childhood, socialization goals, parental roles, and family relations combine to create culturally distinctive social environments for children. Future research might examine differences in how adults understand the inner lives and emotional experiences of children. It could document how parents set standards for children's emotional regulation, behavioral compliance, and social competencies. It could explore whether different outcomes result from the tendency of adults to encourage some responses to developmental challenges children face and to sanction others. It would be important to know how much attributes thought to be valued in the United States are related to positive outcome in the developing world. These attributes include parents' investment in their children's lives, promotion of psychological autonomy, and functional independence. Differences in these domains are suggested by notable differences in the ratings made by South African parents of their children's behaviors, emotions, and social functioning. South African parents are less likely than African Americans to ascribe aversive cognitive or emotional states to their children. Typically these experiences of anxiety or sadness are not readily observable, and inferences are guided by a conception of childhood that includes differentiated affect. The views of African American parents about the emotional experiences of their children are not clear. Thus the connection between differential views of childhood and ratings of emotional function is speculation that must be subjected to empirical tests. Differences between African Americans and South Africans are most pronounced on symptoms that involve observable and potentially disruptive or disturbing behavior. South African parents make markedly higher ratings than do African American parents on these items. This difference does not occur with symptoms that are cognitive, emotional, or social in nature and which are not easily observable.

South Africans, however, are no more ready to characterize their children as disobedient than are African American parents. Differences in the behavioral ratings of South Africans and African Americans may reflect a stricter standard held by South African parents for compliance on the part of their children. Some support for this higher expectation is available in the comparatively high frequency with which South African parents report that their children break rules, are impulsive, and destroy things. This interpretation is consistent with the commonly held belief that African parents value compliance and demand immediate and complete obedience (Liddell, Kvalsvig, Shabalala, \& Qotyana, 1994). If this belief is true, it appears that African children, for the most part, meet this expectation.

The results of this cross-national comparative study provide support for claims of an independent effect of social risk factors of gender and poverty. At 
the same time they cast doubt on a role of female headship that is independent of economic status. In light of the controls for racial categorization, the differences observed between African American and South African children provide an opening for explanations of child outcomes that are based on culture and sociopolitical context. This study demonstrates that there are identifiable similarities between urban dwellers in the United States and those in South Africa with respect to socioeconomic situations, and that there are putative differences with respect to cultural mores and world views. The differences reported here justify additional research on how, on the one hand cultures mediate development of behavioral and emotional problems, and on the other they serve as a basis for resilience and coping. Future research programs on ethnicity, culture, and child adjustment could specifically explore possible healthpromoting factors such as spirituality, racial identity, and sociocultural resources that seem to safeguard South African children from deleterious effects of adverse social conditions.

\section{ACKNOWLEDGMENTS}

Support for the collection of data and preparation of this report was provided by the Office of the Provost, and the Vice President for Research, and by a NIH Fogarty International Center Minority International Training Fellowship, through the University of Michigan Center for Human Growth and Development. The author gratefully acknowledges the dedication of interviewers who worked with him in South Africa, and the generosity of families who so willingly gave of their time to participate in this study.

\section{ADDRESS AND AFFILIATION}

Corresponding author: Oscar A. Barbarin, South Africa Initiative Office, Office of the Vice President for Research, 1065 Freize Building, University of Michigan, Ann Arbor, MI 48109-1285; e-mail: Barbarin@ umich.edu.

\section{REFERENCES}

Achenbach, T. M., Howell, C. T., Quay, H. C., \& Conners, C. K. (1991). National survey of problems and competencies among four- to sixteen-year-olds: Parents' reports for normative and clinical samples. Monographs of the Society for Research in Child Development, 56(3, Serial No. 225).

Barbarin, O. A., \& Khomo, N. (1997). Indicators of economic status and social capital in South African townships: What do they reveal about the material and social condi- tions in families of poor children? Childhood: A Global Journal of Child Research, 4, 193-222.

Barbarin, O., Richter, L., de Wet, T., \& Wachtel, A. (1998). Ironic trends in the transition to peace: Criminal violence supplants political violence in terrorizing South African Blacks. Peace and Conflict: Journal of Peace Psychology, 4, 283-305.

Barbarin, O., \& Soler, R. (1993). Behavioral, emotional and academic adjustment in a national probability sample of African American children: Effects of age, gender and family structure. Journal of Black Psychology, 19, 423-446.

Brooks-Gunn, J., \& Duncan, G. (1997). The effects of poverty on children. The Future of Children: Children and Poverty, 7 , 55-71.

Bureau of Market Research (1995). The October Household Survey. Pretoria, S.A.: University of Pretoria.

Bussing, R., Halfon, N., Benjamin, B., \& Wells, K. (1995). Prevalence of behavior problems in U.S. children with asthma. Archives of Pediatrics and Adolescent Medicine, 149, 565-572.

Capaldi, D. M., \& Patterson, G. R. (1994). Interrelated influences of contextual factors on antisocial behavior in childhood and adolescence for males. In D. C. Fowles, P. Sutker, \& S. H. Goodman (Eds.), Progress in experimental personality and psychopathology research (pp. 165-198). New York: Springer.

Costello, E. J. (1989). Child psychiatric disorders and their correlates: A primary care pediatric sample. Journal of the American Academy of Child and Adolescent Psychiatry, 28, 851-855.

Duncan, G. J., \& Brooks-Gunn, J. (1997). Consequences of growing up poor. New York: Russell Sage Foundation.

Foster, S. L., \& Martinez, C. R., Jr. (1995). Ethnicity: Conceptual and methodological issues in child clinical research. Journal of Clinical Child Psychology, 24, 214-226.

Frederick D. Patterson Research Institute. (1997). The African American education data book (Vol. 2). Alexandria, VA: United Negro College Fund.

Garrison, C. Z., Jackson, K. L., Marsteller, F., McKeown, R., \& Addy, C. (1990). A longitudinal study of depressive symptomatology in young adolescents. Journal of the American Academy of Child and Adolescent Psychiatry, 29, 581-585.

Gore, S., Aseltine, R. H., \& Colton, M. E. (1993). Gender, social-relational involvement, and depression. Journal of Research on Adolescence, 3, 101-125.

Halpern-Felsher, B., Connell, J. P., Spencer, M., Aber, J., Duncan, G., Clifford, E., Crichlow, W., Usinger, P., Cole, S., Allen, L., \& Seidman, E. (1997). Neighborhood and family factors predicting educational risk and attainment in African American and White children and adolescents. In J. Brooks-Gunn, G. Duncan, \& J. Aber (Eds.), Neighborhood poverty: Context and consequences for children (Vol. 2, pp. 146-173). New York: Russell Sage Foundation.

Hammen, C., \& Rudolph, K. D. (1996). Childhood depression. In E. J. Mash \& R. A. Barkley (Eds.), Child psychopathology (pp. 153-195). New York: Guilford Press.

Herrnstein, R. J., \& Murray, C. (1994). The bell curve: Intelligence and class structure in American life. New York: Free Press. 
Hollingshead, A. B. (1957). Two factor index of social position. New Haven, CT: Yale University, Department of Sociology.

Jagers, R., \& Mock, L. (1993). Culture and outcomes among inner-city African American children: An Afrographic exploration. Journal of Black Psychology, 19, 391-405.

Kincheloe, J., Steinberg, S. R., \& Gresson, A. (1996). Measured lies: The bell curve examined. New York: Saint Martin's Press.

Liddell, C., Kvalsvig, J., Shabalala, A., \& Qotyana, P. (1994). Defining the cultural context of children's everyday experiences in the year before school. In A. Dawes \& D. Donald (Eds.), Childhood and adversity: Psychological perspectives from South African research (pp. 51-65). Cape Town, SA: David Phillip.

Lyons, R. K. (1996). Attachment relationships among children with aggressive behavior problems: The role of disorganized early attachment patterns. Journal of Consulting and Clinical Psychology, 64, 64-73.

McKendrick, G., \& Senoamadi, W. (1996). Some effects of violence on squatter camp families and their children. In L. E. Glanz \& A. D. Spiegel (Eds.), Violence and family life in contemporary South Africa: Research and policy issues (pp. 15-28). Pretoria, SA: Human Sciences Research Council Publishers.

McLoyd, V. C. (1998). Socioeconomic disadvantage and child development. American Psychologist, 53, 185-204.

National Center for Health Statistics. (1988). Child Health Supplement National Health Interview Survey. Hyattsville, MD: Public Health Service.

Neal, A. M., Lilly, R. S., \& Zakis, S. (1993). What are African American children afraid of? A preliminary study. Journal of Anxiety Disorders, 7, 129-139.

Nielsen, F. (1997). Inequality by design: Cracking the Bell Curve myth. Social Forces, 76, 701-704.

Offord, D. R., Alder, R. J., \& Boyle, M. H. (1986). Prevalence and sociodemographic correlates of conduct disorder. American Journal of Social Psychiatry, 4, 272-278.

Ollendick, T. H. (1983). Fear in children and adolescents: Normative data. Behavior Research and Therapy, 23, 465-467.

Peterson, J., \& Zill, N. (1986). Marital disruption, parentchild relationships, and behavior problems in children. Journal of Marriage and the Family, 48, 295-307.

Pollitt, E., \& Gorman, K. (1994). Nutritional deficiencies as developmental risk factors. In C. A. Nelson (Ed.), The Minnesota Symposium on Child Psychology: Vol. 27. Threats to optimal development: Integrating biological, psychological, and social risk factors (pp. 1-31). Hillsdale, NJ: Erlbaum.

Richter, L. M. (1994). Economic stress and its influence on the family and caretaking patterns. In A. Dawes \& D. Donald (Eds.), Childhood and adversity: Psychological perspectives from South African research (pp. 28-50). Cape Town, SA: David Phillip.

Richter, L. M., Yach, D., Cameron, N., Griesel, R. D., \& de Wet, T. (1995). Enrollment into Birth to Ten (BTT): Population and sample characteristics. Pediatrics and Perinatal Epidemiology, 9, 109-120.

Richters, J. E. (1993). Community violence and children's development: Toward a research agenda for the 1990s. Psychiatry, 53, 3-6.

Robertson, B. A., \& Kottler, A. (1993). Cultural issues in the psychiatric assessment of Xhosa children and adolescents. South African Medical Journal, 83, 207-208.

Stevenson, H. W., Chen, C., \& Uttal, D. H. (1990). Beliefs and achievement: A study of Black, White, and Hispanic children. Child Development, 61, 508-523.

Suzuki, L. A., \& Valencia, R. R. (1997). Race-ethnicity and measured intelligence: Educational implications. American Psychologist, 52, 1103-1114.

Swarts, M. (1997). The family: Cradle of violence in South Africa. Human Sciences Research Council: In Focus Forum, 4(5), 40-44.

U.S. Bureau of the Census. (1993). Poverty in the United States: 1992 (Current Population Reports, Series P-60, No. 185). Washington, DC: U.S. Government Printing Office.

Werner, E., \& Smith, R. (1989). Vulnerable but invincible: A longitudinal study of resilient children and youth. New York: Adams, Bannister, and Cox.

Whitaker, A., Johnson, J., Shaffer, D., Rapoport, J. L., Kalikow, K., Walsh, B. T., Davies, M., Braiman, S., \& Dolinsky, A. (1990). Uncommon troubles in young people: Prevalence estimates of selected psychiatric disorders in a non-referred adolescent population. Archives of General Psychiatry, 47, 487-496.

Wood, F. B., Felton, R. H., Flowers, L., \& Naylor, C. (1991). Neurobehavioral definition of dyslexia. In D. D. Duane \& D. B. Gray (Eds.), The reading brain: The biological basis of dyslexia (pp. 1-26). Parkton, MD: York Press.

Zill, N. (1985). Behavior Problem Scales developed from the 1981 Child Health Supplement to the National Health Interview Survey. Washington, DC: Child Trends. 